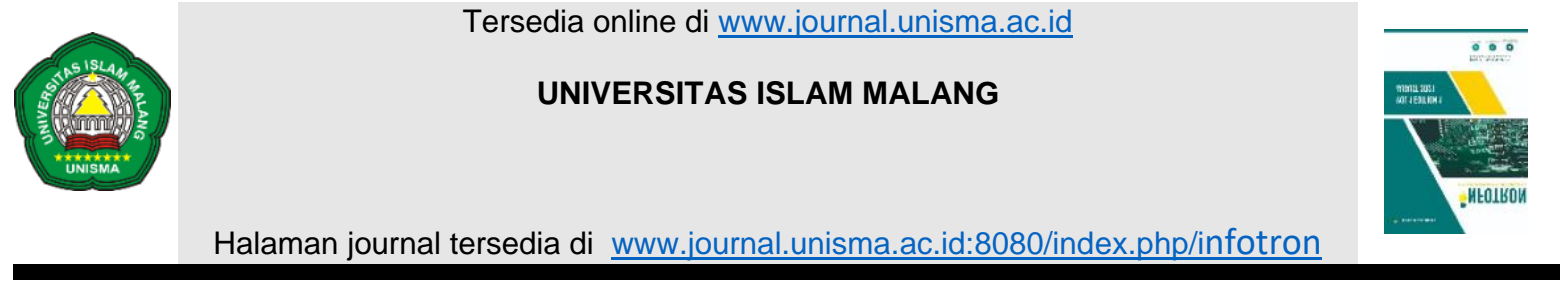

\title{
Pengujian Sistem Monitoring Listrik Berbasis NodeMCU Menggunakan Blackbox Testing
}

\author{
Muhammad Fatih Yordani ${ }^{a}$, Aris Sudaryanto ${ }^{b}$ \\ a Teknik Informatika, Universitas 17 Agustus 1945 Surabaya, Surabaya, Indonesia \\ ${ }^{b}$ Teknik Informatika, Universitas 17 Agustus 1945 Surabaya, Surabaya, Indonesia \\ email:ayordani689@gmail.com,baris@untag-sby.ac.id
}

\begin{tabular}{l}
\hline INFORMASI \\
ARTIKEL \\
\hline
\end{tabular}

Kata kunci:

IoT

NodeMCU

ESP 8266

Sensor PZEM

Website

\begin{abstract}
A B S T R A K
Tingkat konsumsi listrik di Indonesia semakin meningkat dari tahun ke tahun. Disisi lain, mayoritas pembangkit listrik di Indonesia masih mengandalkan bahan bakar fossil. Maka mau tidak mau, harus dilakukan penghematan atau efisiensi konsumsi listrik. Cara alternatif untuk dapat menyadarkan masyarakat untuk mengefisienkan dan menghemat konsumsi listrik adalah dengan memberikan info secara realtime dan kontinyu tentang konsumsi listrik mereka. Caranya adalah dengan sistem monitoring listrik berbasis NodeMCU ini. Namun untuk mengetahui keandalannya, sistem perlu dilakukan pengujian. Paper penelitian ini focus untuk menguji fungsional sistem monitoring listrik berbasis NodeMCU menggunakan metode blackbox testing. Seluruh fungsional sistem diuji satu per satu baik dari sisi hardware maupun software. Hasil pengujian sistem yang telah dilakukan menunjukkan bahwa fungsional sistem monitoring listrik berbasis NodeMCU ini bekerja cukup baik dengan tingkat keberhasilan mencapai 100\%.
\end{abstract}

\section{Pendahuluan}

Konsumsi listrik di Indonesia semakin meningkat dari waktu ke waktu [1]. Padahal mayoritas listrik di Indonesia masih diproduksi menggunakan bahan bakar fosil yang semakin lama akan semakin habis [2]. Maka mau tidak mau seluruh masyarakat harus menghemat dan mengefisienkan konsumsi listriknya. Berangkat dari permasalahan tersebut maka peneliti berinisiatif untuk merancang sebuah system monitoring pemakaian listrik berbasis NodeMCU ini. System terdiri dari NodeMCU sebagai pengendali utama, sensor PZEM untuk monitoring konsumsi listrik, LCD dan website sebagai tampilan, serta relay untuk memutuskan atau menyambungkan rangkaian listrik. Namun untuk mengetahui keandalan system, perlu dilakukan pengujian terlebih dahulu. Penelitian ini focus untuk mengukur keandalan system dengan menggunakan metode uji blackbox testing.

\section{State of the Art}

Terkait dengan metode pengujian blackbox testing, sebelumnya telah cukup banyak penelitian yang menggunakan metode blackbox testing. Pada tahun 2018 dalam papernya yang berjudul "Pengujian Aplikasi dengan Metode Blackbox Testing Boundary Value Analysis (Studi Kasus: Kantor Digital Politeknik Negeri Lampung)", Tri Snadhika Jaya menggunakan metode blackbox testing boundary value analysis untuk menguji software Kantor Digital Politeknik Negeri Lampung. Hasil dari pengujian 
tersebut, diketahui bahwa software Kantor Digital Politeknik Negeri Lampung mampu menangani berbagai data dengan tingkat kemampuan mencapai 91,67\% [3].

Penelitian terkait monitoring konsumsi listrik dilakukan oleh Anggher Pangestu dkk pada 2018. Dalam papernya yang berjudul "SISTEM MONITORING BEBAN LISTRIK BERBASIS ARDUINO NODEMCU ESP8266" dipaparkan bahwa Anggher Pangestu dkk membuat sebuah sistem monitoring beban listrik, dengan control utama adalah NodeMCU ESP8266, dan ACS712 sebagai sensor arus. Sebagai data display digunakan LCD dan aplikasi Blynk. Hasilnya, alat tersebut memiliki akurasi dalam membaca data sensor sebesar 96\% hingga 98\% [4]. Namun kelamahan aplikasi Blynk biasanya tidak dapat bekerja secara real time, karena terjadi delay pada setiap proses pengiriman setiap data.

Dalam paper lainnya, Adam dkk melakukan penelitian serupa yaitu membuat sebuah sistem untuk memonitoring arus dan tegangan. Penelitian tersebut dipublikasikan dalam paper berjudul "Sistem Monitoring Arus Dan Tegangan Menggunakan SMS Gateway". Sistem ini menggunakan Arduino sebagai pengendali utama, sedangkan untuk mengukur konsumsi listrik digunakan sensor arus AC SCT 013-000 dan sensor tegangan ZMPT101B, terakhir modul SIM 800L sebagai perangkat notifikasi untuk mengirimkan SMS (short message service). Berdasarkan pengujian yang dilakukan, modul SIM 800L bekerja cukup baik dengan tingkat keberhasilan mencapai 80\% [5].

Ikwan dkk dalam papernya yang berjudul "PERANCANGAN SISTEM MONITORING DAN KONTROLING PENGGUNAAN DAYA LISTRIK BERBASIS ANDROID" pada tahun 2020 membuat sistem yang fungsinya serupa. Sebagai pengendali utama menggunakan NodeMCU ESP8266 V3, sedangkan untuk mengukur konsumsi listrik digunakan sensor PZEM-004T. Untuk tampilan monitoring menggunakan aplikasi android yang didukung dengan NoSQL dari Firebase yang bersifat realtime. Sedangkan perintah kendali dikirimkan melalui API Telegram [6]. Sayangnya tidak disebutkan dalam paper, hasil pengujian keseluruhan sistem tingkat keberhasilannya mencapai berapa persen.

Pada tahun 2020 Aris Sudaryanto dkk mempublikasikan paper penelitian berjudul "Pengujian Stop Kontak Pintar Menggunakan ESP 32". Dalam penelitian tersebut dibuat sebuah stop kontak pintar yang nyala dan matinya dapat dikendalikan melalui aplikasi android yang terhubung dengan jaringan internet. Pengendali utama dari sisi hardware pada sistem ini adalah ESP32 yang sekaligus berfungsi untuk komunikasi data dengan aplikasi android pada sisi pengguna. Untuk memutus dan menyambungkan rangkaian listrik, digunakan modul relay. Perintah diberikan oleh pengguna melalui aplikasi android, perintah tersebut dikirimkan ke ESP32 melalui jaringan internet, lalu ESP32 akan meneruskan perintah dari pengguna ke relay untuk memutuskan atau menyambungkan rangkaian listrik. Dari hasil pengujian yang telah dilakukan, sistem yang dibuat dapat $100 \%$ bekerja dengan baik [7]. Namun Stop Kontak Pintar yang dibuat pada penelitian ini masih belum terdapat fitur monitoring konsumsi listrik. Maka kemudian penelitian dikembangkan lagi menjadi Sistem Monitoring Listrik Berbasis NodeMCU ini.

Pengendali putus atau sambungnya aliran listrik pada penelitian ini menggunakan relay 2 channel. Penggunaan relay sebagai pengendali aliran listrik merupakan hal yang cukup umum digunakan dalam penelitian. Seperti halnya penelitian yang dilakukan oleh [8] Anton Breva dkk, yang menggunakan relay 12 Volt untuk mengendalikan solenoid valve pada alat pengendali volume air rumah kos.

\section{Method}

Write some words of tile ...

(c) 2021 INFOTRON: Jurnal IImiah Teknik Informatika, Elektronika dan Kontrol (Scientific Journal of Informatics, Electronics and Control Engineering). Copyrights. All rights reserved. 
Monitoring pemakaian listrik berbasis arduino merupakan sistem yang bertujuan untuk memberikan informasi tentang data listrik pada suatu ruangan. Website pada system ini digunakan oleh user untuk memonitoring data arus, tegangan, daya, $\mathrm{KwH}$, dan total perkiraan biaya listrik serta mengontrol sumber listrik pada ruangan menggunakan website. Pada pengujian perangkat lunak dan perangkat keras digunakan teknik black box yang memiliki arti bahwa pengujian yang dilakukan hanya mengambil hasil eksekusi melalui data uji dan memeriksa fungsional dari perangkat lunak dan perangkat keras.

Blackbox Testing yaitu salah satu teknik pengujian perangkat lunak yang fokusnya pada spesifikasi fungsional dari perangkat lunak. Dengan adanya Balckbox Testing memungkinkan pengembang perangkat lunak untuk membuat kumpulan suatu keadaan input pada suatu program yang akan melatih seluruh syarat-syarat fungsionalnya.

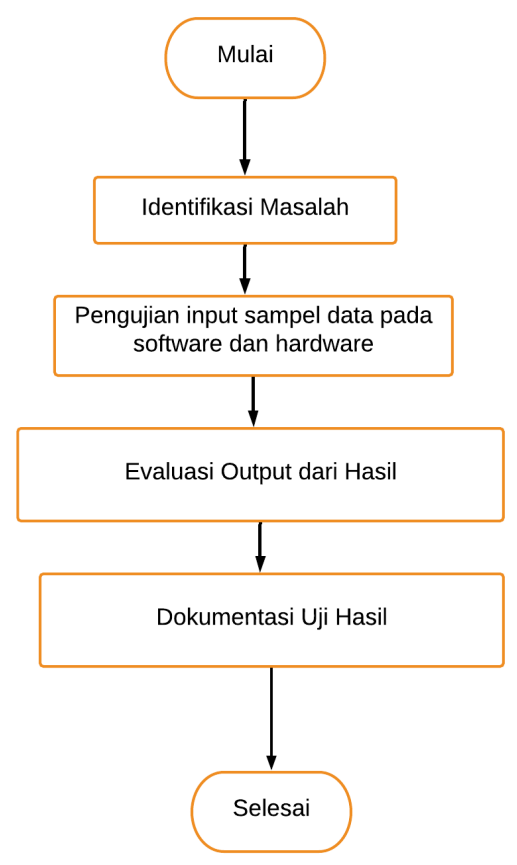

Gambar 1. Diagram alir penelitian

\section{Hasil and Pembahasan}

Pada penelitian ini digunakan metode pengujian blackbox testing pada system baik dari sisi hardware maupun software. Dari sisi hardware, ada empat fungsional yang diuji yaitu fungsi koneksi NodeMCU ke jaringan, fungsi sensor PZEM, fungsi relay 2 channel dan fungsi LCD display. Sedangkan fungsional dari sisi software yang diuji adalah form login, modul menu dashboard, modul menu laporan dan terakhir menu relay.

Tabel 1. Hasil uji fungsi koneksi NodeMCU ESP8622

\begin{tabular}{ccccc}
\hline No & Pengujian & Hasil Yang Diharapkan & Hasil Pengujian & Kesimpulan \\
\hline 1 & Terhubung ke internet & $\begin{array}{c}\text { NodeMCU terkoneksi } \\
\text { dengan internet }\end{array}$ & Sesuai Harapan & Valid \\
\hline & Tingkat keberhasilan & & $100 \%$
\end{tabular}

Table 1 merupakan hasil dari pengujian blackbox testing fungsional NodeMCU untuk terkoneksi dengan jaringan internet. Fungsi ini penting karena akan menjadi jalur utama komunikasi antara 
pengguna dengan sistem. Hasil pengujian pada table 1 menunjukkan bahwa fungsi koneksi NodeMCU untuk terhubung ke internet $100 \%$ bekerja sesuai harapan.

Tabel 2. Blackbox Testing Pada Sensor PZEM-004T

\begin{tabular}{|c|c|c|c|c|}
\hline No & Pengujian & Hasil Yang Diharapkan & Hasil Pengujian & Kesimpulan \\
\hline 1 & $\begin{array}{l}\text { Sensor PZEM1 } \\
\text { mendeteksi Arus }\end{array}$ & $\begin{array}{c}\text { Sensor PZEM1 dapat } \\
\text { mendeteksi Arus pada stop } \\
\text { kontak kamar } 1\end{array}$ & Sesuai Harapan & Valid \\
\hline 2 & $\begin{array}{c}\text { Sensor PZEM1 } \\
\text { mendeteksi Tegangan }\end{array}$ & $\begin{array}{c}\text { Sensor PZEM1 dapat } \\
\text { mendeteksi Tegangan pada } \\
\text { stop kontak kamar } 1\end{array}$ & Sesuai Harapan & Valid \\
\hline 3 & $\begin{array}{c}\text { Sensor PZEM1 } \\
\text { mendeteksi Daya }\end{array}$ & $\begin{array}{c}\text { Sensor PZEM1 dapat } \\
\text { mendeteksi Daya pada stop } \\
\text { kontak kamar } 1\end{array}$ & Sesuai Harapan & Valid \\
\hline 4 & $\begin{array}{c}\text { Sensor PZEM1 } \\
\text { mendeteksi KwH }\end{array}$ & $\begin{array}{l}\text { Sensor PZEM1 dapat } \\
\text { mendeteksi KwH pada } \\
\text { stop kontak kamar } 1\end{array}$ & Sesuai Harapan & Valid \\
\hline 5 & $\begin{array}{l}\text { Sensor PZEM2 } \\
\text { mendeteksi Arus }\end{array}$ & $\begin{array}{c}\text { Sensor PZEM2 dapat } \\
\text { mendeteksi Arus pada stop } \\
\text { kontak kamar } 2\end{array}$ & Sesuai Harapan & Valid \\
\hline 6 & $\begin{array}{c}\text { Sensor PZEM2 } \\
\text { mendeteksi Tegangan }\end{array}$ & $\begin{array}{c}\text { Sensor PZEM2 dapat } \\
\text { mendeteksi Tegangan pada } \\
\text { stop kontak kamar } 2\end{array}$ & Sesuai Harapan & Valid \\
\hline 7 & $\begin{array}{l}\text { Sensor PZEM2 } \\
\text { mendeteksi Daya }\end{array}$ & $\begin{array}{c}\text { Sensor PZEM2 dapat } \\
\text { mendeteksi Daya pada stop } \\
\text { kontak kamar } 2\end{array}$ & Sesuai Harapan & Valid \\
\hline 8 & $\begin{array}{l}\text { Sensor PZEM2 } \\
\text { mendeteksi KwH }\end{array}$ & $\begin{array}{c}\text { Sensor PZEM2 dapat } \\
\text { mendeteksi KwH pada } \\
\text { stop kontak kamar } 2\end{array}$ & Sesuai Harapan & Valid \\
\hline & Tingkat keberhasilan & & & $100 \%$ \\
\hline
\end{tabular}

Selanjutnya dilakukan pengujian terhadap sensor PZEM yang digunakan pada sistem. Poin poin yang diuji dari sensor PZEM antara lain adalah pengukuran arus, pengukuran tegangan, pengukuran daya, dan pengukuran $\mathrm{KwH}$. Karena sensor PZEM yang digunakan ada dua, maka juga dilakukan pengujian terhadap keduanya (dibedakan dengan penyebutan sensor PZEM1 dan sensor PZEM2). Pengujian ini bertujuan untuk mengetahui apakah sensor PZEM mampu mendeteksi arus, tegangan, daya serta $\mathrm{KwH}$. Berdasarkan data hasil pengujian yang disajikan pada Table 2, terlihat bahwa seluruh pengujian bernilai valid dengan tingkat keberhasilan $100 \%$. Hal tersebut berarti bahwa sensor PZEM yang digunakan dapat berfungsi dengan baik.

Tabel 3. Hasil uji relay 2 channel

\begin{tabular}{ccccc}
\hline No & Pengujian & Hasil Yang Diharapkan & Hasil Pengujian & Kesimpulan \\
\hline 1 & Channel 1 On & $\begin{array}{c}\text { Led pada relay menyala } \\
\text { dan stop kontak pada } \\
\text { kamar 1 hidup } \\
\text { Led pada relay mati dan } \\
\text { stop kontak pada kamar 1 } \\
\text { mati }\end{array}$ & Sesuai Harapan & Valid \\
3 & Channel 1 Off & $\begin{array}{c}\text { Led pada relay menyala } \\
\text { dan stop kontak pada } \\
\text { kamar 2 hidup }\end{array}$ & Sesuai Harapan & Valid \\
& & &
\end{tabular}

Write some words of tile...

(C) 2021 INFOTRON: Jurnal IImiah Teknik Informatika, Elektronika dan Kontrol (Scientific Journal of Informatics, Electronics and Control Engineering). Copyrights. All rights reserved. 


\begin{tabular}{|c|c|c|}
\hline Channel 2 Off & $\begin{array}{c}\text { Led pada relay mati dan } \\
\text { stop kontak pada kamar } 2 \\
\text { mati }\end{array}$ & Sesuai Harapan \\
\hline
\end{tabular}

Tingkat keberhasilan

$100 \%$

Fungsional sisi hardware urutan ketiga yang diuji adalah relay 2 channel. Pengujian ini bertujuan untuk mengetahui relay yang digunakan dapat bekerja dengan baik atau tidak. Pengujian dilakukan dengan cara menyalakan atau mematikan relay, kemudian melihat pengaruhnya terhadap stop kontak dan LED indikator relay. Jika relay OFF, maka seharusnya LED indikator akan mati dan stop kontak juga mati. Sebaliknya jika relay ON, maka seharusnya LED indikator menyala dan stop kontak juga menyala. Kesesuaian kondisi relay dengan LED indicator serta stop kontak ini kemudian dicatat sebagai hasil pengujian. Data hasil pengujian relay pada table 3 menunjukkan bahwa relay 2 channel bekerja dengan baik dan sesuai dengan tingkat keberhasilan $100 \%$.

Tabel 4. Hasil uji fungsional LCD

\begin{tabular}{|c|c|c|c|c|}
\hline No & Pengujian & Hasil Yang Diharapkan & Hasil Pengujian & Kesimpulan \\
\hline 1 & LCD 1 & $\begin{array}{l}\text { Lcd menampilkan data } \\
\text { KwH dan total perkiraan } \\
\text { harga listrik pada stop } \\
\text { kontak kamar } 1\end{array}$ & Sesuai Harapan & Valid \\
\hline 2 & LCD 2 & $\begin{array}{l}\text { Lcd menampilkan data } \\
\text { KwH dan total perkiraan } \\
\text { harga listrik pada stop } \\
\text { kontak kamar } 2\end{array}$ & Sesuai Harapan & Valid \\
\hline \multicolumn{3}{|c|}{ Tingkat keberhasilan } & & $100 \%$ \\
\hline
\end{tabular}

Fungsional terakhir dari sisi hardware yang diuji adalah LCD display. Pengujian ini bertujuan untuk mengukur kemampuan LCD display dalam menampilkan informasi berupa data $\mathrm{KwH}$, perkiraan harga listrik dan status stop kontak. Terlihat dari table 4 yang merupakan hasil pengujian LCD display, bahwa fungsional LCD bekerja baik dengan tingkat keberhasilan mencapai $100 \%$.

Fungsional dari sisi software yang diuji pada penelitian ini ada empat, yaitu form menu login, menu dashboard, menu laporan dan menu relay. 


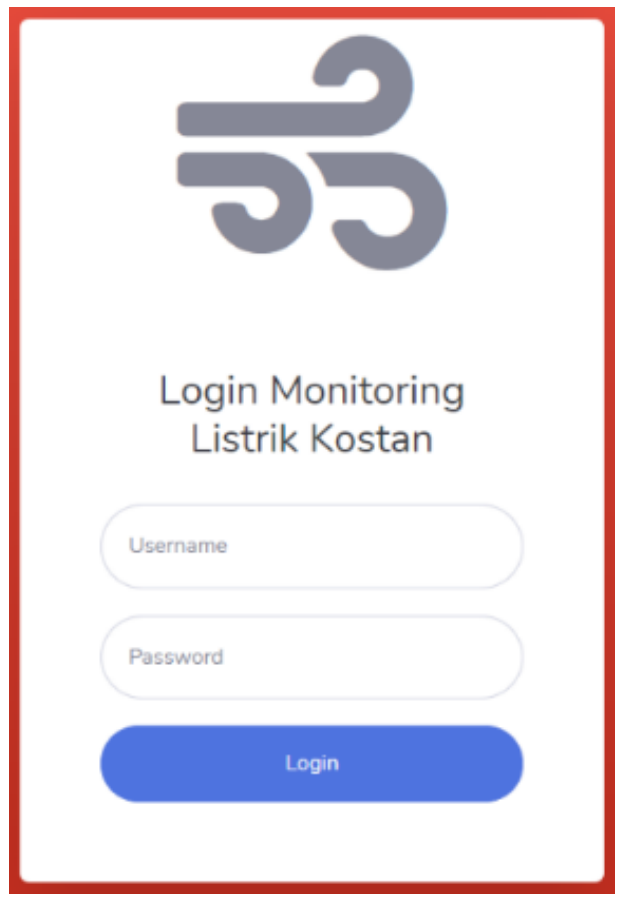

Gambar 2. Tampilan menu login

Tabel 5. Hasil uji menu login

\begin{tabular}{|c|c|c|c|c|}
\hline No & Pengujian & Hasil Yang Diharapkan & Hasil Pengujian & Kesimpulan \\
\hline 1 & $\begin{array}{c}\text { Masukkan username } \\
\text { dan password yang } \\
\text { tidak terdaftar }\end{array}$ & $\begin{array}{l}\text { User tidak dapat masuk ke- } \\
\text { menu utama }\end{array}$ & Sesuai Harapan & Valid \\
\hline 2 & $\begin{array}{c}\text { Masukkan username } \\
\text { dan password yang } \\
\text { terdaftar }\end{array}$ & $\begin{array}{l}\text { User mendapatkan akses ke } \\
\text { menu utama }\end{array}$ & Sesuai Harapan & Valid \\
\hline 3 & $\begin{array}{l}\text { Masukkan username } \\
\text { saja }\end{array}$ & $\begin{array}{l}\text { Terdapat peringatan untuk } \\
\text { memasukkan password }\end{array}$ & Tidak Sesuai Harapan & Invalid \\
\hline 4 & $\begin{array}{c}\text { Masukkan password } \\
\text { saja }\end{array}$ & $\begin{array}{l}\text { Terdapat peringatan untuk } \\
\text { masukkan username }\end{array}$ & Tidak Sesuai Harapan & Invalid \\
\hline \multirow[t]{2}{*}{5} & $\begin{array}{l}\text { Logout pada halaman } \\
\text { website }\end{array}$ & $\begin{array}{l}\text { Keluar dari halaman website } \\
\text { dan Kembali ke halaman login }\end{array}$ & Sesuai Harapan & Valid \\
\hline & Tingkat keberhasilan & & & $100 \%$ \\
\hline
\end{tabular}

Pengujian pertama dari sisi software adalah pada form login. Pengujian ini bertujuan untuk melihat apakah form login yang dibuat dapat bekerja dengan baik sesuai ketentuan atau tidak. Pengujian dilakukan dengan lima scenario, yaitu memasukkan username dan password yang tidak terdaftar, memasukkan username dan password yang terdaftar, memasukkan username saja, measukkan password saja, serta menu logout. Setelah diberi masukan sesuai scenario, kemudian respon atau keluaran dari form login akan diamati dan dibandingkan apakah sesuai atau tidak sesuai dengan respon atau keluaran yang seharusnya diberikan oleh form login tersebut. Hasil pengujian menu login pada Tabel 5 menunjukkan bahwa fungsi menu login berhasil bekerja 100\% dengan baik. 


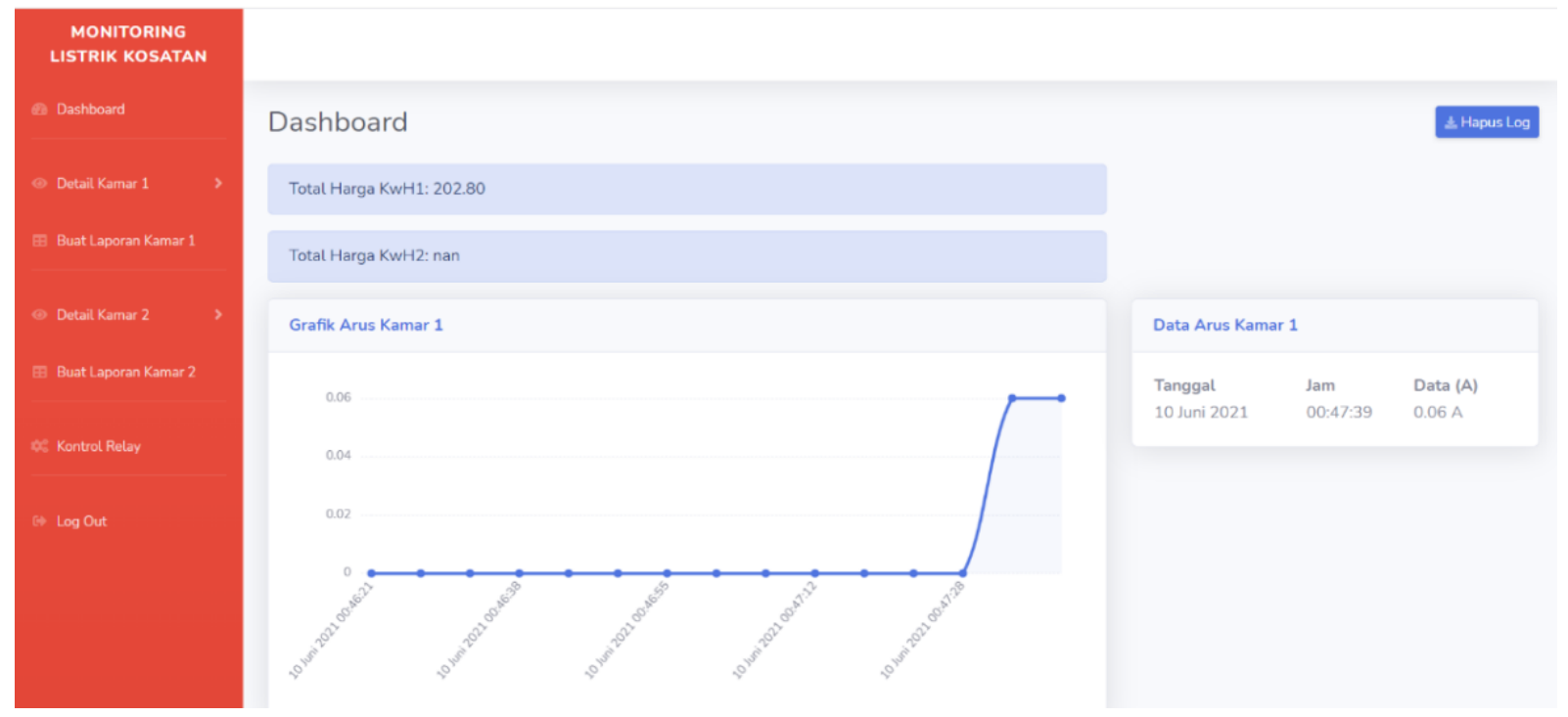

Gambar 3. Tampilan menu dashboard

Tabel 6. Hasil uji menu dashboard

\begin{tabular}{ccccc}
\hline No & Pengujian & Hasil Yang Diharapkan & Hasil Pengujian & Kesimpulan \\
\hline 1 & $\begin{array}{c}\text { Menampilkan data } \\
\text { sensor }\end{array}$ & $\begin{array}{c}\text { Grafik pada halaman berisikan } \\
\text { nilai arus, tegangan, daya dan } \\
\text { KwH }\end{array}$ & Sesuai Harapan & Valid \\
2 & $\begin{array}{c}\text { Menampilkan Tanggal, } \\
\text { Jam serta data sensor }\end{array}$ & $\begin{array}{c}\text { Card menampilkan tanggal, jam } \\
\text { dan data secara realtime } \\
\text { Alert berwarna biru } \\
\text { menampilkan data total } \\
\text { perkiraan biaya listrik }\end{array}$ & Sesuai Harapan & Sesuai Harapan \\
Menampilkan perkiraan \\
biaya listrik \\
4 & $\begin{array}{c}\text { Menghapus data sensor } \\
\text { Dengan menekan button } \\
\text { hapus log }\end{array}$ & Data sensor terhapus & Sesuai Harapan & Valid \\
\hline & Tingkat keberhasilan & & & $100 \%$ \\
\hline
\end{tabular}

Pengujian kedua dari sisi software adalah menu dashboard. Pengujian ini bertujuan untuk melihat tingkat keberhasilan menu dashboard dalam menampilkan informasi berupa tegangan, arus, daya, $\mathrm{KwH}$, data waktu, data perkiraan biaya, serta fungsi menghapus log. Dari Tabel 6 yang merupakan data hasil pengujian menu dashboard, terlihat bahwa fungsi menampilkan data arus, tegangan, daya dan $\mathrm{KwH}$ bekerja 100\% dengan baik. Sedangkan fungsi menampilkan keterangan waktu juga 100\% dapat bekerja dengan baik. Fungsi perkiraan biaya listrik juga 100\% dapat ditampilkan dengan baik. Terakhir fungsi menghapus log dengan cara menekan tombol hapus log juga bekerja dengan baik 100\%. Keseluruhan menu dashboard dapat bekerja 100\% dengan baik. 


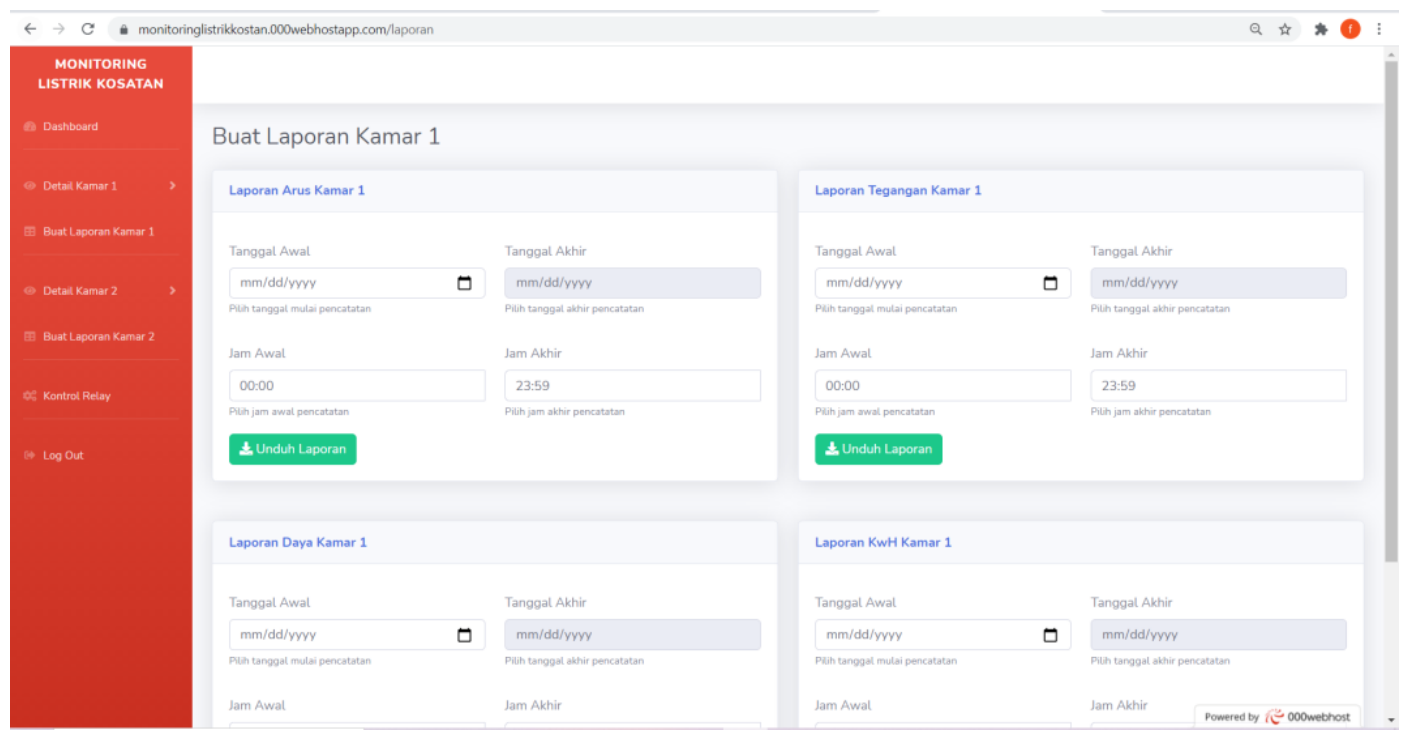

Gambar 4. Tampilan menu laporan

Tabel 7. Hasil uji menu laporan

\begin{tabular}{|c|c|c|c|c|}
\hline No & Pengujian & Hasil Yang Diharapkan & Hasil Pengujian & Kesimpulan \\
\hline 1 & $\begin{array}{l}\text { Buat laporan pada Arus } \\
\text { kamar } 1\end{array}$ & $\begin{array}{l}\text { Dapat mendownload laporan } \\
\text { dengan format pdf dengan data } \\
\text { yang sesuai pada Arus kamar } 1\end{array}$ & Sesuai Harapan & Valid \\
\hline 2 & $\begin{array}{l}\text { Buat laporan pada } \\
\text { Tegangan kamar } 1\end{array}$ & $\begin{array}{c}\text { Dapat mendownload laporan } \\
\text { dengan format pdf dengan data } \\
\text { yang sesuai pada Tegangan } \\
\text { kamar } 1\end{array}$ & Sesuai Harapan & Valid \\
\hline 3 & $\begin{array}{c}\text { Buat laporan pada Daya } \\
\text { kamar } 1\end{array}$ & $\begin{array}{l}\text { Dapat mendownload laporan } \\
\text { dengan format pdf dengan data } \\
\text { yang sesuai pada Daya kamar } 1\end{array}$ & Sesuai Harapan & Valid \\
\hline 4 & $\begin{array}{l}\text { Buat laporan pada Kwh } \\
\text { kamar } 1\end{array}$ & $\begin{array}{l}\text { Dapat mendownload laporan } \\
\text { dengan format pdf dengan data } \\
\text { yang sesuai pada } \mathrm{KwH} \text { kamar } 1\end{array}$ & Sesuai Harapan & Valid \\
\hline 5 & $\begin{array}{l}\text { Buat laporan pada Arus } \\
\text { kamar } 2\end{array}$ & $\begin{array}{l}\text { Dapat mendownload laporan } \\
\text { dengan format pdf dengan data } \\
\text { yang sesuai pada Arus kamar } 2\end{array}$ & Sesuai Harapan & Valid \\
\hline 6 & $\begin{array}{l}\text { Buat laporan pada } \\
\text { Tegangan kamar } 2\end{array}$ & $\begin{array}{c}\text { Dapat mendownload laporan } \\
\text { dengan format pdf dengan data } \\
\text { yang sesuai pada Tegangan } \\
\text { kamar } 2\end{array}$ & Sesuai Harapan & Valid \\
\hline 7 & $\begin{array}{c}\text { Buat laporan pada Daya } \\
\text { kamar } 2\end{array}$ & $\begin{array}{l}\text { Dapat mendownload laporan } \\
\text { dengan format pdf dengan data } \\
\text { yang sesuai pada Daya kamar } 2\end{array}$ & Sesuai Harapan & Valid \\
\hline 8 & $\begin{array}{l}\text { Buat laporan pada Kwh } \\
\text { kamar } 2\end{array}$ & $\begin{array}{l}\text { Dapat mendownload laporan } \\
\text { dengan format pdf dengan data } \\
\text { yang sesuai pada } \mathrm{KwH} \text { kamar } 2\end{array}$ & Sesuai Harapan & Valid \\
\hline & Tingkat keberhasilan & & & $100 \%$ \\
\hline
\end{tabular}

Pengujian ketiga dari sisi software adalah menu laporan. Menu laporan ini pada intinya bertujuan untuk memberikan informasi konsumsi listrik kepada pengguna untuk hari hari tertentu saja. Informasi

Write some words of tile ...

(c) 2021 INFOTRON: Jurnal IImiah Teknik Informatika, Elektronika dan Kontrol (Scientific Journal of Informatics, Electronics and Control Engineering). Copyrights. All rights reserved. 
yang dilaporkan berupa tanggal, tegangan, arus, daya dan $\mathrm{KwH}$ dan total perkiraan biaya yang harus dibayarkan oleh pengguna atas konsumsi listriknya. Karena sensor pada sistem ini ada dua buah, maka kedua sensor tersebut tetap diuji dengan masing masing diuji keberhasilannya dalam menampilkan informasi arus, tegangan, daya, $\mathrm{KwH}$ serta perkiraan biaya total. Dari Table 7 yang merupakan hasil uji menu laporan, dapat disimpulkan bahwa semua fungsi pada menu laporan $100 \%$ dapat bekerja dengan baik.

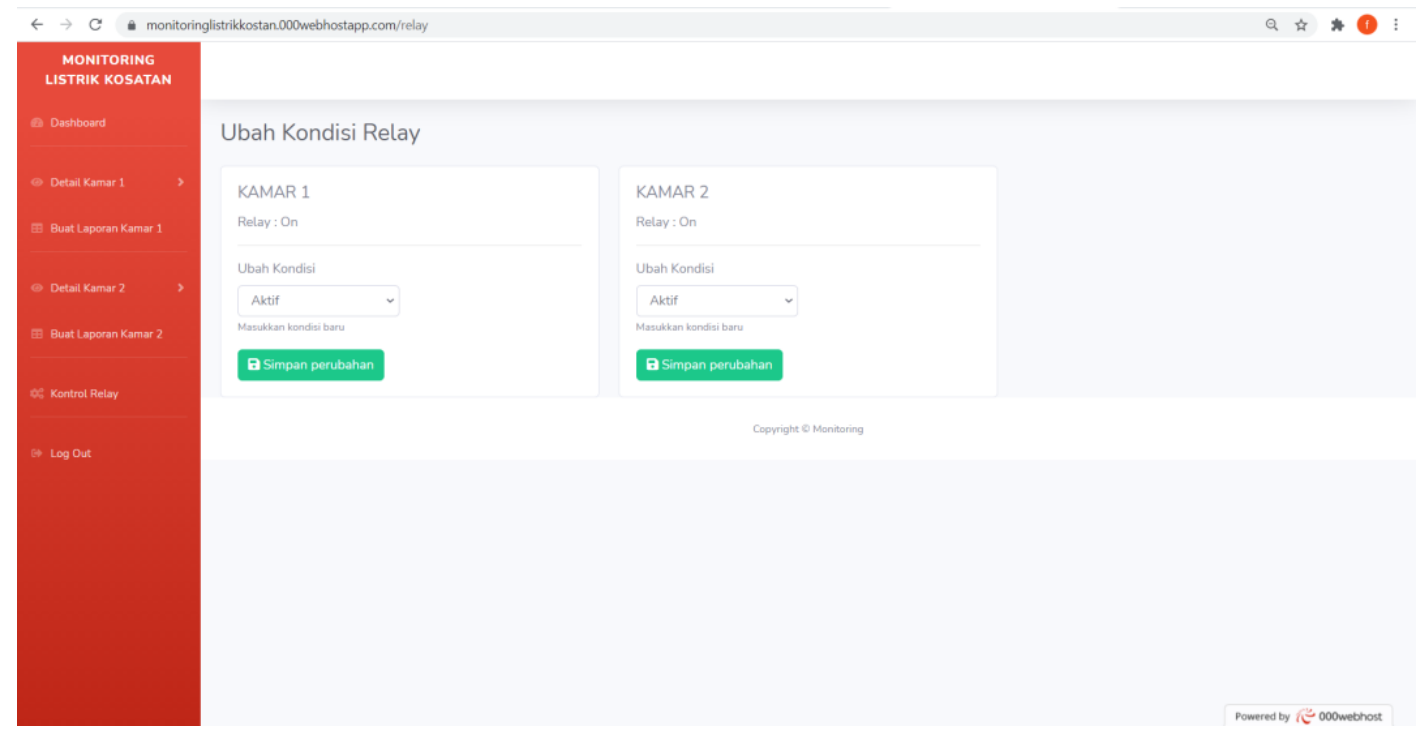

Gambar 5. Tampilan menu relay

Tabel 8. Hasil uji menu relay

\begin{tabular}{|c|c|c|c|c|}
\hline No & Pengujian & Hasil Yang Diharapkan & Hasil Pengujian & Kesimpulan \\
\hline 1 & $\begin{array}{c}\text { Status ON Relay } \\
\text { Channel } 1\end{array}$ & Stop kontak pada kamar 1 hidup & Sesuai Harapan & Valid \\
\hline 2 & $\begin{array}{l}\text { Status Off Relay } \\
\text { Channel } 1\end{array}$ & Stop kontak pada kamar 1 mati & Sesuai Harapan & Valid \\
\hline 3 & $\begin{array}{l}\text { Status ON Relay } \\
\text { Channel } 2\end{array}$ & Stop kontak pada kamar 2 hidup & Sesuai Harapan & Valid \\
\hline \multirow[t]{2}{*}{4} & $\begin{array}{c}\text { Status Off Relay } \\
\text { Channel } 1\end{array}$ & Stop kontak pada kamar 2 mati & Sesuai Harapan & Valid \\
\hline & Tingkat keberhasilar & & & $100 \%$ \\
\hline
\end{tabular}

Pengujian terakhir dari sisi software adalah menu relay. Menu laporan ini pada intinya bertujuan untuk membantu pengguna mengendalikan hidup atau matinya rangkaian listrik. Pengujian dilakukan dengan cara pengguna memberi masukan perintah berupa relay $\mathrm{ON}$ atau relay OFF, kemudian diamati kesesuaiannya dengan LED indicator dan status stop kontak. Jika perintah relay ON maka seharusnya akan diikuti dengan kondisi LED indicator menyala dan stop kontak juga menyala. Sebaliknya jika perintah relay OFF maka seharusnya akan diikuti dengan kondisi LED indicator padam dan stop kontak juga mati. Hasil pengujian menu relay yang ditampilkan pada Tabel 8 menunjukkan bahwa menu relay $100 \%$ bekerja dengan baik dan sesuai scenario. 


\section{Kesimpulan dan Saran}

Berdasarkan pengujian yang telah dilakukan, diketahui bahwa baik dari sisi software maupun hardware, seluruh fungsional sistem dapat berjalan baik dengan tingkat keberhasilan $100 \%$.

Sedangkan sebagai pengembangan sistem kedepan, menurut peneliti ada beberapa hal yang mungkin masih dapat diteliti dan dikembangkan. Hal tersebut antara lain adalah pengujian keandalan sistem dari sisi hardware. Pengembangan sistem terkait dengan penyimpanan dan pengolahan data juga menjadi hal yang cukup penting, karena sebenarnya sensor dapat mengambil data secara real time, akan tetapi semakin banyak data yang diambil akan semakin membebani sistem, maka perlu dilakukan efisiensi berapa data yang sebetulnya penting dan perlu diambil.

\section{Refrensi}

[1] A. Lidwina, “Konsumsi Listrik Nasional Terus Meningkat," 2020. https://databoks.katadata.co.id/datapublish/2020/01/10/konsumsi-listrik-nasional-terusmeningkat.

[2] V. F. Thomas, “Energi Fosil Sumbang 85\% Listrik RI per Mei 2020, Terbanyak PLTU," 2020. https://tirto.id/energi-fosil-sumbang-85-listrik-ri-per-mei-2020-terbanyak-pltu-fU1K.

[3] T. S. Jaya, "Pengujian Aplikasi Dengan Metode Blackbox Testing Boundary Value Analysis (Studi Kasus: Kantor Digital Politeknik Negeri Lampung)," J. Inform. J. Pengemb. IT, vol. 3, no. 2, pp. 45-48, 2018.

[4] A. D. Pangestu, F. Ardianto, and B. Alfaresi, "Sistem Monitoring Beban Listrik Berbasis Arduino Nodemcu Esp8266," J. Ampere, vol. 4, no. 1, p. 187, 2019, doi: 10.31851/ampere.v4i1.2745.

[5] A. Adam, H. Amri, and Miswan, "Prototype Monitoring Arus Dan Tegangan Menggunakan Sms Gateway," Multitek Indones. J. Ilm., vol. 13, no. 1, p. 16, 2019, doi: 10.24269/mtkind.v13i1.1710.

[6] Ikwan; Djaksana Yan Mita, "PERANCANGAN SISTEM MONITORING DAN KONTROLING PENGGUNAAN DAYA LISTRIK BERBASIS ANDROID," JURSISTEKNI (Jurnal Sist. Inf. dan Teknol. Informasi), vol. 2, no. 3, pp. 13-24, 2020.

[7] A. Sudaryanto, A. E. Wahyudianto, and A. Rizaldi, "Pengujian Stop Kontak Pintar Menggunakan ESP 32," J. Teknol. Inf. Dan Komun., vol. 11, no. September, pp. 27-30, 2020, doi: https://doi.org/10.51903/jtikp.v11i2.

[8] A. B. Yunanda, A. Darwanto, and A. Sudaryanto, "PENGENDALI VOLUME AIR UNTUK RUMAH KOS BERBASIS ARDUINO," J. KONVERGENSI, vol. 14, no. 2, pp. 54-59, 2018, doi: https://doi.org/10.30996/konv.v14i2. 